\title{
Frequency and types of human papillomavirus among pregnant and non-pregnant women with human immunodeficiency virus infection in Recife determined by genotyping
}

\author{
Vírginia da Conceição Ribes Amorim Bezerra Brandão $0^{1,2,3 /+}$, Heloisa Ramos Lacerda ${ }^{2,4}$, \\ Norma Lucena-Silva ${ }^{5,6}$, Ricardo Arraes de Alencar Ximenes ${ }^{2,4}$ \\ 'Centro Integrado de Saúde Amaury de Medeiros, Recife, PE, Brasil 2Programa de Pós-Graduação em Medicina Tropical, \\ Universidade Federal de Pernambuco, Recife, PE, Brasil ${ }^{3}$ Departamento de Patologia ${ }^{4}$ Departamento de Medicina Interna, Universidade \\ de Pernambuco, Recife, PE, Brasil ${ }^{5}$ Centro de Pesquisa Aggeu Magalhães-Fiocruz, Recife, PE, Brasil ${ }^{6}$ Instituto de Medicina Integral \\ Prof. Fernando Figueira, Recife, PE, Brasil
}

Women with human immunodeficiency virus (HIV) infection present a higher risk of infection by the human papillomavirus (HPV) and cervical cancer. To determine HPV genotypes and frequencies among HIV-positive women, an analytical cross-sectional study was carried out on 147 women (51 were pregnant and HIV-positive, 45 pregnant and $H I V$-negative and 51 HIV-positive and not pregnant), who were attended at a maternity hospital in Recife between April 2006-May 2007. They answered a questionnaire and underwent a gynaecological examination, with samples collected for HPV investigation by PCR, hybrid capture II, oncotic colpocytology (Papanicolau) and colposcopy. The frequency of HPV DNA was $85.3 \%$ (122/143), with a high proportion of HPV types that have been identified as high risk for cervical cancer. Among HIV-positive pregnant women, there was an HPV prevalence of 96\% (48/50), of whom 60.4\% (29/48) were high-risk. HPV 16, 58, 18, 66 and 31 were the most frequent types. Colpocytological abnormalities were observed in 35.3\% (18/51) of HIV-positive non-pregnant women, $21.6 \%$ (11/51) of HIV-positive pregnant women and $13.3 \%$ (6/45) of HIV-negative pregnant women with a predominance of low-level lesions. A high prevalence of HPV infection was identified, especially with the high-risk types 16, 58, 18 and 66. This study identified high-risk HPV types in all three groups examined (HIV-positive pregnant women, HIV-negative pregnant women and HIV-positive not pregnant), characterising its distribution in this setting.

Key words: human papillomavirus - human immunodeficiency virus - squamous intraepithelial lesion - pregnancy polymerase chain reaction

Genital infection due to oncogenic types of human papillomavirus (HPV) is the main etiological factor for uterine cervical cancer, although it is not sufficient by itself to cause the disease. In fact, the coexistence of various factors that allow the transition from infection to cancer is necessary (Nicol et al. 2005, Muñoz et al. 2006, Villa \& Denny 2006, Zimmermann et al. 2006). The viral factors include the genotype, viral load, persistency and viral DNA integration with the host cell genome (Lillo et al. 2005). The host factors include an early start to sexual relations, multiparity (Muñoz et al. 2003), multiple sexual partners (Muñoz et al. 2006) oral contraceptive use (Moreno et al. 2002, Castrllsague \& Muñoz 2003), smoking (Castrllsague \& Muñoz 2003, Harris et al. 2004) and a history of sexually transmissible diseases such as herpes simplex (Hessol et al. 2004), Chlamydia trachomatis (Di Felice et al. 2005, Trotier \& Franco 2006, Wright et al. 2006, Madaleine et al. 2007) and acquired immunodeficiency syndrome (Berrébi et al. 2008, Denny et al. 2008).

Financial support: MS, PAHO

+Corresponding author: ribes_amorim@yahoo.com.br

Received 4 February 2009

Accepted 26 June 2009
Various studies have shown that cervical intraepithelial lesions (IEL) are more frequent and recurrent among seropositive women, with faster progression and worse response to standard treatment (Ellerbrock et al. 2000, Duerr et al. 2001, Jamieson et al. 2002, Ferenczy et al. 2003, Coelho et al. 2004, Levi et al. 2004, Campos et al. 2005, Palefsky 2006, Denny et al. 2008). This greater aggressiveness has a direct relationship with high-risk HPV genotypes, which are more frequent in the cervix of women infected with human immunodeficiency virus (HIV) (Berrébi et al. 2008).

The high prevalence of HPV among HIV-positive women can be explained by the tendency for HPV to persist, thus differing from what occurs among immunocompetent individuals (Nappi et al. 2005, Hawes et al. 2006, Palefsky 2006, Berrébi et al. 2008, Denny et al. 2008).

A reduction in immunity occurs during the gestational period. Specifically in the genital organs, the vaginal flora presents an imbalance that, associated with the greater dampness particular to that area, favours the development of infectious agents, among them HPV. Moreover, the hormonal factors and immunosuppression, which are necessary for maintaining a foetus, predispose a woman to the acquisition and development of lesions induced by HPV (Rando et al. 1989, Armbruster-Moraes et al. 2000, Costa et al. 2000, Correia et al. 2006). Anatomical modifications of the genital 
tract such as hypertrophy, congestion and ectopy also increase, followed by metaplasia. The area of immature squamous metaplasia is more susceptible to the development of preneoplastic lesions and HPV infections (Mota 2002, Correia et al. 2006).

The incidence of HPV increases over the course of pregnancy (Schneider et al. 1987, Rando et al. 1989, Meisels 1992), with variations according to the population studied, gestational phase and diagnostic technique. During the first trimester of pregnancy, there is a low immune response to HPV, which explains the higher frequency of persistence of the virus during pregnancy. However, this deficient response undergoes an intense recovery at the start of the third trimester, with reinforcement during the postpartum period and consequent regression of the infection (Puig-Tintoré et al. 2002).

The main objective of the present study was to evaluate the frequency and main types of HPV detected among HIV-positive pregnant women in Recife and to compare these findings with those among seronegative pregnant women and HIV-positive women who were not pregnant.

\section{PATIENTS, MATERIALS AND METHODS}

This was an analytical, cross-sectional study on 51 HIV-positive pregnant women who were attended at the Centro Integrado de Saúde Amaury de Medeiros (CISAM), Recife, Pernambuco, between April 2006May 2007. Two comparison groups were formed. The first consisted of $51 \mathrm{HIV}$-positive women who were not pregnant, seen at Hospital Correia Picanço, State Health Department of Pernambuco, Recife or at CISAM and the second consisted of 45 HIV-negative pregnant women who came to CISAM for antenatal consultations. CISAM is a state reference unit for HIV-positive pregnant women, but it is also attended by HIV-negative women. Correia Picanço Hospital is the state reference unit for HIVpositive patients. Patients were consecutively selected in both units during the study period.

The diagnosis of HIV infection was confirmed by means of two ELISA tests and one confirmatory test (indirect immunofluorescence) (MS 2005). Pregnancy was confirmed by means of a positive $\beta$-HCG examination or a confirmatory pregnancy ultrasound. The group of HIV-positive women who were not pregnant included women with HIV that had been confirmed using the above tests, but who were negative for $\beta$-HCG at the time of the examination. The HIV-negative pregnant women were selected from among those who sought the antenatal outpatient clinic of CISAM at any time during the pregnancy and were negative for anti-HIV (ELISA).

In all seropositive patients, the most recent quantification of HIV viral load and TCD4-lymphocyte count was registered, provided that it had been carried out not more than six months before the time of the interview/ examination. The viral load was quantified by means of the Cobas Amplicor HIV-1 monitoring test $\left(\right.$ Roche $^{\circledR}$ ), which uses the PCR technique and $\mathrm{CD}^{+}$lymphocytes were quantified using flow cytometry.

Patients were excluded if they presented with genital bleeding, intense vulvovaginitis at the time of the examination or any mental deficit.
The patients who agreed to participate in the study signed a free and informed consent statement and answered a questionnaire. A gynaecological examination was carried out, following a pre-established sequence: (i) the inspection insertion of a vaginal speculum, (ii) collection of material for HPV identification using PCR (MY09/ MY11) and hybrid capture II (HC II) and (iii) collection of material for oncotic colpocytological examination.

After insertion of the vaginal speculum, a brush (cytobrush $^{\circledR}$ ) was used to collect material from the endocervix. The material was distributed in a TE buffer solution (Tris- $\mathrm{HCl}+$ ethylenediaminetetracetic acid in $\mathrm{pH} 8$ ) by shaking the brush in a previously identified Eppendorf tube. The samples were then transported to the Molecular Biology Laboratory of the Professor Fernando Figueira Integral Medicine Institute. DNA extraction, PCR and sequencing were used to detect HPV DNA. DNA extraction was carried out using the proteinase $\mathrm{K}$ technique, in which $20 \mu \mathrm{L}$ of proteinase $\mathrm{K}$ enzyme $(10 \mathrm{mg} / \mathrm{mL}$, Invitrogen, USA) was added to $100 \mu \mathrm{L}$ of the sample. This solution was incubated at $65^{\circ} \mathrm{C}$ (overnight), followed by a thermal shock at $95^{\circ} \mathrm{C}$ for $10 \mathrm{~min}$. The extracted DNA was first submitted to amplification of a human constitutive gene $(g p d H)$ to verify the quality of the DNA obtained. Samples that were positive for gpdH (glucose phosphate dehydrogenase) amplification were then submitted to the specific amplification for HPV detection using primers MY09 and MY11 and reagents supplied by Invitrogen (USA) as described by Manos et al. (1989). A negative control (no DNA) was included in each PCR run to ensure no cross contamination. The PCR product was submitted to $1 \%$ agarose gel electrophoresis, stained with ethidium bromide and visualised on a transilluminator using ultraviolet light. The DNA bands from all positive samples were purified and sequenced to identify the HPV type using the Big-Dye protocol, as recommended by the manufacturer and the Genetic Analysing ABI 3100 sequencer, with 96 capillary tubes (Applied Biosystems, USA). The results were analysed with the aid of the BlastN tool, which is available from the website of the National Centre for Biotechnology Information (2007) (http://www.ncbi.nlm.nih.gov/).

For the Hybrid Capture II, the manufacturer's technical protocols were followed. With the uterine cervix exposed, samples were collected with a single-use sterile swab at the entrance to the endocervix, the ectocervix and the vaginal walls. The biological specimens were packed in tubes containing transportation buffer (Specimen Transport Medium, STM) and were sent within 12 days to Digene Brazil (São Paulo, Brazil) for interpretation. The HC II uses RNA probes that are highly specific for detecting 18 types of HPV divided into two groups: group A (low-risk HPV, subtypes 6, 11, 42, 43 and 44) and group B (high and intermediate-risk HPV, subtypes $16,18,31,33,35,39,45,51,52,56,58,59$ and $68)$. The results were presented using relative light unit (RLU) value for the sample/calibrator. The RLU rate for the examination to be considered positive was 1.0, which corresponds to $1 \mathrm{pg} / \mathrm{mL}$ of HPV DNA.

The next step consisted of collecting material for oncotic cytological examination, using Ayre's spatula to 
scrape the ectocervix (squamocolumnar junction) and a brush (cytobrush ${ }^{\circledR}$ ) to collect an endocervical sample. The smears were placed on previously identified glass slides and fixed with $95 \%$ alcohol. After staining using the Papanicolaou method, the smears were evaluated in the Cytopathology Laboratory of CISAM. The reports issued were based on the Bethesda system (Berek 2003).

Colposcopy was the final stage of the examination. Firstly, a $0.9 \%$ physiological solution was introduced for cervical inspection. Next, $3 \%$ acetic acid was applied to the uterine cervix, with the aim of investigating areas that were reactive to it. Schiller's test was performed using Lugol and the examination was concluded. The colposcopic image descriptions were in line with the Rome international classification for the nomenclature of colposcopic characteristics, as authenticated by the International Federation for Cervical Pathology and Colposcopy (Walker et al. 2003).

The data were stored and analysed using Epi-Info software, version 6.04 and SPSS software, version 9.0 and the variables were described as percentages. HPV proportions among groups were analysed using Pearson's chi-squared test. A p value $<0.05$ was considered statistically significant.

This study and research project had previously been evaluated and approved by the Ethical in Research Committee of the University of Pernambuco (protocol CISAM/009/05).

\section{RESULTS}

The three groups analysed in the present study were shown to be similar in various demographic and socioeconomic categories (Table I). Women in the three groups were of lower socioeconomic status, none of them had reached a university level or had a salary greater than three times the minimum wage. There was a higher proportion of adolescents in the HIV-positive pregnant women than in the HIV-positive non-pregnant group and the HIV-negative pregnant group. Most of the women in all three groups were either married or had a permanent partner (Brandão 2008). Though age and the number of sexual partners were associated to belonging to the three groups, they were not associated with HPV infection: age and HPV infection $(p=0.504)$; number of sexual partners and HPV infection (0.185). The predominant form of contamination among the HIV-infected patients was sexual contact. Patient characteristics relating to time of diagnosis of HIV infection, $\mathrm{CD}^{+}$lymphocyte count, HIV viral load and antiretroviral therapy are shown in Table II. There was a difference, though not statistically significant, in relation to the stage of pregnancy $(0.0876)$ between the two groups of pregnant women. Age group $(\mathrm{p}=0.493)$, number of sexual partners $(0.986)$, diagnosis of HIV infection (0.390) and CD4 ${ }^{+}$lymphocyte count $(\mathrm{p}=0.368)$ were not associated with HPV infection, although they were associated with pregnancy in HIVpositive women. Only the use of antiretroviral therapy

TABLE I

Comparison of the groups regarding the socio-demographic characteristics among women attended at CISAM - April 2006-May 2007

\begin{tabular}{|c|c|c|c|c|c|c|c|}
\hline \multirow[b]{3}{*}{ Variables } & \multicolumn{6}{|c|}{ Groups } & \multirow[b]{3}{*}{ p-value } \\
\hline & \multicolumn{2}{|c|}{$\begin{array}{c}\text { Pregnant HIV+ } \\
n=51\end{array}$} & \multicolumn{2}{|c|}{$\begin{array}{l}\text { Non-pregnant HIV+ } \\
\qquad \mathrm{n}=51\end{array}$} & \multicolumn{2}{|c|}{$\begin{array}{c}\text { Pregnant HIV- } \\
n=45\end{array}$} & \\
\hline & $\mathrm{n}$ & $\%$ & $\mathrm{n}$ & $\%$ & $\mathrm{n}$ & $\%$ & \\
\hline \multicolumn{8}{|l|}{ Age Group } \\
\hline$\leq 19$ & 10 & 19.6 & 01 & 2.0 & 04 & 8.9 & 0.001 \\
\hline $20-29$ & 33 & 64.7 & 23 & 45.1 & 23 & 51.1 & \\
\hline$\geq 30$ & 08 & 15.7 & 27 & 52.9 & 18 & 40.0 & \\
\hline \multicolumn{8}{|l|}{ Marital status } \\
\hline Single & 09 & 17.6 & 06 & 11.8 & 03 & 6.7 & 0.372 \\
\hline Married/living together & 37 & 72.5 & 38 & 74.5 & 39 & 86.7 & \\
\hline Separeted/divordec/widowed & 05 & 9.8 & 07 & 13.7 & 03 & 6.7 & \\
\hline \multicolumn{8}{|l|}{ Sexual partners (n) } \\
\hline $1-2$ & 14 & 27.5 & 12 & 23.5 & 24 & 53.3 & 0.001 \\
\hline $3-4$ & 17 & 33.3 & 28 & 54.9 & 16 & 35.6 & \\
\hline$\geq 5$ & 20 & 39.2 & 11 & 21.6 & 05 & 11.1 & \\
\hline \multicolumn{8}{|l|}{ Level of education } \\
\hline Incomplete primary education & 21 & 41.2 & 14 & 27.5 & 12 & 26.7 & 0.051 \\
\hline Primary education & 16 & 31.4 & 23 & 45.1 & 11 & 24.4 & \\
\hline Incomplete secundary education & 14 & 27.5 & 14 & 27.5 & 22 & 48.9 & \\
\hline \multicolumn{8}{|l|}{ Income (MW) } \\
\hline$<1$ & 42 & 82.4 & 38 & 74.5 & 35 & 77.8 & 0.628 \\
\hline $1-3$ & 09 & 17.6 & 13 & 25.5 & 10 & 22.2 & \\
\hline
\end{tabular}

CISAM: Centro Integrado de Saúde Amaury de Medeiros; HIV: human immunodeficiency virus; MW: minimum wage. 
was associated with both the group (0.000) and HPV infection (0.037). When both variables were introduced in a bivariate model, only group remained in the model, indicating that the association with group is independent of the use of antiretroviral therapy.

Of the 147 patients, one HIV-positive pregnant woman and three HIV-positive non-pregnant women $(2.7 \%)$ were negative for GPDH (i.e., their samples had inhibitors of the amplification reaction). Using PCR, 21 of the 143 patients examined using the in-house PCR protocol were negative for HPV DNA and 122 patients were positive for HPV DNA (85.3\%). The HIV-positive pregnant group had the highest percentage ( $96 \%$ or $48 / 50$ patients). Figure shows the frequency distribution of HPV DNA in the three study groups.

For four of the 122 patients who were positive for HPV DNA (3.3\%), it was not possible to type the HPV strain; this was possibly due to infection by multiple types of HPV, which makes the interpretation of the ambiguous sequence difficult using the software. In all of the study groups, the high-risk type of HPV was predominant (Table III).

HPV was detected using hybrid capture in 67 of the 147 patients studied (45.6\%), with the following distribution: HIV-positive pregnant women, $62.7 \%$ (32/51), HIVpositive non-pregnant women, $52.9 \%(27 / 51)$ and HIVnegative pregnant women, $17.7 \%(8 / 45)$. Among the 32 HIV-positive pregnant women, $30(93.8 \%)$ had high-risk HPV and the eight HIV-negative pregnant women were all positive for high-risk HPV (Table IV).

\section{TABLE II}

Time of diagnosis, immunological and virological parameters and use of antiretroviral therapy among HIV-infected pregnant and non-pregnant women attended at CISAM April 2006-May 2007

\begin{tabular}{|c|c|c|c|c|c|}
\hline \multirow[b]{3}{*}{ Variables } & \multicolumn{4}{|c|}{ Groups } & \multirow[b]{3}{*}{ p-value } \\
\hline & \multicolumn{2}{|c|}{$\begin{array}{c}\text { Pregnant } \\
\text { HIV+ } \\
n=51\end{array}$} & \multicolumn{2}{|c|}{$\begin{array}{c}\text { Non-pregnant } \\
\text { HIV+ } \\
\mathrm{n}=51\end{array}$} & \\
\hline & $\mathrm{n}$ & $\%$ & $\mathrm{n}$ & $\%$ & \\
\hline \multicolumn{6}{|c|}{ Diagnosis of HIV infection } \\
\hline$<1$ year & 29 & 56.9 & 12 & 23.5 & 0.003 \\
\hline $1-2$ years & 8 & 15.7 & 10 & 19.6 & \\
\hline $3-5$ years & 12 & 23.5 & 19 & 37.3 & \\
\hline$>5$ years & 2 & 3.9 & 10 & 19.6 & \\
\hline \multicolumn{6}{|c|}{$\mathrm{CD} 4^{+}$lymphocyte count } \\
\hline$<200$ & 4 & 7.8 & 11 & 21.6 & 0.073 \\
\hline $201-500$ & 21 & 41.2 & 23 & 45.1 & \\
\hline$>501$ & 26 & 51.0 & 17 & 33.3 & \\
\hline \multicolumn{6}{|l|}{ HIV viral load } \\
\hline$<10,000$ & 37 & 72.5 & 36 & 70.6 & 0.967 \\
\hline $10,000-100,000$ & 9 & 18.8 & 10 & 19.6 & \\
\hline$>100,000$ & 5 & 10.4 & 5 & 9.8 & \\
\hline \multicolumn{6}{|c|}{ Antiretroviral therapy } \\
\hline No & 7 & 13.7 & 28 & 54.9 & 0.000 \\
\hline Monotherapy & 9 & 17.6 & - & - & \\
\hline Polytherapy & 35 & 68.7 & 23 & 45.1 & \\
\hline
\end{tabular}

CISAM: Centro Integrado de Saúde Amaury de Medeiros; HIV: human immunodeficiency virus.
The hybrid capture II and PCR molecular methods were compared in the 143 patients who underwent both tests. Although there was a significant agreement between the PCR and HC II methods $(p=0.031)$, it translated to a weak kappa value of 0.119 . PCR did not detect HPV DNA in five samples (1 HIV-positive pregnant woman, 3 HIV-positive non-pregnant women and 1 HIV-negative pregnant woman), while the HC II method failed to detect it in 62 samples (Table V). The sensitivity of HC II was $49.2 \%$, its specificity was $76.2 \%$, PPV was $92.3 \%$ and NPV was $20.5 \%$.

Of the 62 samples shown to be false negatives by HC II, $66.1 \%(41 / 62)$ had types of HPV that were not included in probes A and/or B. Theremaining 33.9\% (21/62) consisted of HPV types that were included in theprobes.

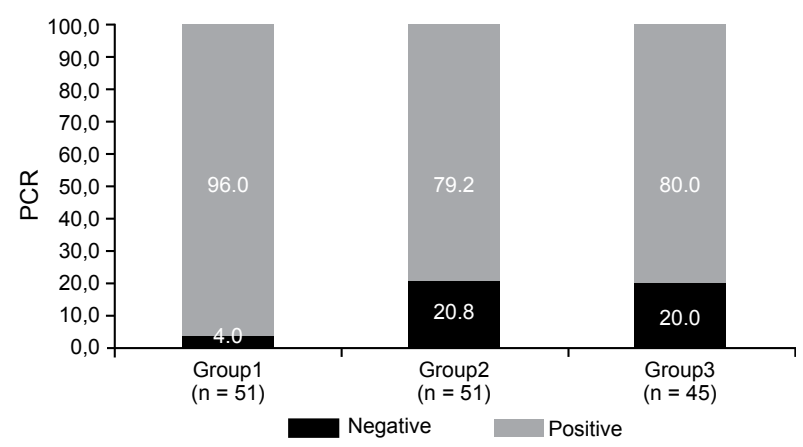

Frequency of human papillomaviruz DNA detected using the polymerase chain reaction (PCR) in the three study groups.

\section{TABLE III}

Distribution of the human papillomavirus (HPV) types identified by genotyping and cytological findings among 147 women attended at CISAM - April 2006-May 2007

\begin{tabular}{lccrr}
\hline & \multicolumn{2}{c}{ Cytological findings } & \multicolumn{2}{c}{ Total } \\
\hline HPV types & IEL & $\begin{array}{c}\text { Normal/inflammatory } \\
\text { cytological findings }\end{array}$ & $\mathrm{n}$ & $\%$ \\
\hline 16 & 6 & 11 & 17 & 13.9 \\
58 & 8 & 6 & 14 & 11.5 \\
18 & - & 11 & 11 & 9.0 \\
66 & 3 & 7 & 10 & 8.2 \\
31 & 3 & 4 & 7 & 5.7 \\
70 & - & 7 & 7 & 5.7 \\
71 & 3 & 3 & 6 & 4.9 \\
53 & 2 & 3 & 5 & 4.1 \\
56 & 1 & 4 & 5 & 4.1 \\
68 & 1 & 4 & 5 & 4.1 \\
11 & 2 & - & 2 & 1.6 \\
62 & 1 & - & 1 & 0.8 \\
82 & 1 & 1 & 2 & 1.6 \\
101 & 2 & - & 2 & 1.6 \\
Mixed & 2 & 7 & 9 & 7.4 \\
Not classified & - & 4 & 4 & 3.3 \\
Others & - & 15 & 15 & 12.3 \\
\hline Total & 35 & 87 & 122 & 100.0 \\
\hline
\end{tabular}

CISAM: Centro Integrado de Saúde Amaury de Medeiros; IEL: intraepithelial lesions. 


\section{TABLE IV}

Comparison of the groups regarding the colposcopic and cytological findings and human papillomavirus DNA identified by means of hybrid capture (HC II) and polymerase chain reaction among women attended at CISAM - April 2006-May 2007

\begin{tabular}{|c|c|c|c|c|c|c|c|}
\hline \multirow{3}{*}{$\begin{array}{l}\text { Colposcopic, cytological and } \\
\text { hybrid capture findings }\end{array}$} & \multicolumn{6}{|c|}{ Groups } & \multirow[b]{3}{*}{ p-value } \\
\hline & \multicolumn{2}{|c|}{$\begin{array}{c}\text { Pregnant HIV+ } \\
\mathrm{n}=51\end{array}$} & \multicolumn{2}{|c|}{$\begin{array}{l}\text { Non-pregnant HIV+ } \\
\qquad \mathrm{n}=51\end{array}$} & \multicolumn{2}{|c|}{$\begin{array}{l}\text { Pregnant HIV- } \\
\mathrm{n}=45\end{array}$} & \\
\hline & $\mathrm{n}$ & $\%$ & $\mathrm{n}$ & $\%$ & $\mathrm{n}$ & $\%$ & \\
\hline \multicolumn{8}{|l|}{ Colposcopic findings ${ }^{a}$} \\
\hline Normal & 26 & 51.0 & 31 & 60.8 & 28 & 62.2 & 0.468 \\
\hline Abnormal & 25 & 49.0 & 20 & 39.2 & 17 & 37.8 & \\
\hline \multicolumn{8}{|l|}{ Colposcopic abnormalities } \\
\hline Acetic white epithelium & 22 & 43.1 & 13 & 25.5 & 14 & 31.1 & \\
\hline Negative iodine & - & - & 3 & 5.9 & - & - & \\
\hline Dotted & - & - & 4 & 7.8 & 2 & 4.4 & \\
\hline Mosaic & 3 & 5.9 & 2 & 3.9 & - & - & \\
\hline Leukoplakia & - & - & 2 & 3.9 & - & - & \\
\hline Atypical vessel & - & - & 3 & 5.9 & 2 & 4.4 & \\
\hline \multicolumn{8}{|l|}{ Cytological abnormalities } \\
\hline Yes & 11 & 21.6 & 18 & 35.3 & 6 & 13.3 & 0.037 \\
\hline No & 40 & 78.4 & 33 & 64.7 & 39 & 86.7 & \\
\hline \multicolumn{8}{|l|}{ Cytological findings } \\
\hline Normal & 8 & 15.7 & 5 & 9.8 & 10 & 22.2 & \\
\hline Inflammatory & 32 & 62.7 & 28 & 54.9 & 29 & 64.4 & \\
\hline ASCUS & 2 & 3.9 & 3 & 5.9 & 1 & 2.4 & \\
\hline Low-grade IEL & 9 & 17.6 & 13 & 25.5 & 4 & 8.9 & \\
\hline High-grade IEL & - & - & 2 & 3.9 & 1 & 2.2 & \\
\hline \multicolumn{8}{|l|}{ Hybrid capture II } \\
\hline Positive & 32 & 62.7 & 27 & 52.9 & 8 & 17.8 & 0.000 \\
\hline Negative & 19 & 37.3 & 24 & 47.1 & 37 & 82.2 & \\
\hline \multicolumn{8}{|l|}{ HPV type (HC II) } \\
\hline High-risk & 16 & 50.0 & 16 & 59.3 & 7 & 87.5 & 0.427 \\
\hline Low-risk & 2 & 6.3 & 1 & 3.7 & - & - & \\
\hline Both & 14 & 43.8 & 10 & 37.0 & 1 & 12.5 & \\
\hline \multicolumn{8}{|l|}{ Polymerase chain reaction } \\
\hline Positive & 48 & 94.11 & 38 & 74.5 & 36 & 80.0 & \\
\hline Negative & 3 & 5.89 & 13 & 25.5 & 9 & 20.0 & \\
\hline
\end{tabular}

a: vulvar condyloma: two pregnant human immunodeficiency virus (HIV) positive women, two pregnant HIV-negative women and three non-pregnant HIV-positive women; CISAM: Centro Integrado de Saúde Amaury de Medeiros; HPV: human papillomavirus; IEL: intraepithelial lesions.

The cytological analysis found a high frequency of smears with inflammatory abnormalities in the three study groups. Abnormalities in squamous cells were more frequently present among the HIV-positive groups, represented by three times as many cases among the seropositive women $(18 ; 35.3 \%)$ and twice as many among the HIV-positive pregnant women $(11 ; 21.6 \%)$, than in the HIV-negative pregnant women $(6 ; 13.3 \%)(p=0.037)$ (Table IV). Among the seropositive women who were not pregnant, $12(66.7 \%)$ presented cytomorphological findings that were compatible with HPV infection: koilocytosis, binucleation and keratinisation. Among the HIV-positive pregnant women, all lesions were low grade and HPV was identified in six patients (54.4\%) through cytological analysis. There were some patients in all groups with more than one colposcopic abnormality, the most frequent of which was acetic white epithelium. Biopsies were not carried out on the women who were pregnant (Puig-Tintoré et al. 2002), except in one case of an HIV-negative pregnant woman presenting colpocytological findings of high-grade intraepithelial lesion (CIN III - Ca in situ), with colposcopic findings of acetic white epithelium and atypical vessels, who had a histological report of in situ carcinoma, although there was the possibility of invasion. This patient underwent high-frequency surgery and grade II invasive epidermoid carcinoma was diagnosed, with multiple foci of vascular invasion. PCR identified HPV 66 and HC II was positive for group B.

\section{DISCUSSION}

In the present study, the prevalence of HPV was highest among the HIV-positive pregnant women and there was a high prevalence of high-risk HPV, regardless of the study group. The cervical environment probably favoured the establishment of oncogenic types of HPV due to the set of local immunological factors, such as 


\section{TABLE V}

Comparison between polymerase chain reaction and hybrid capture results from 147 women attended at CISAM - April 2006-May 2007

\begin{tabular}{lccc}
\hline & \multicolumn{2}{c}{ PCR } & \\
\cline { 2 - 3 } Hybrid capture II & $\begin{array}{c}\text { Negative } \\
\mathrm{n}(\%)\end{array}$ & $\begin{array}{c}\text { Positive } \\
\mathrm{n}(\%)\end{array}$ & $\begin{array}{c}\text { Total } \\
\mathrm{n}(\%)\end{array}$ \\
\hline Negative & $16(76.2)$ & $62(50.8)$ & $78(54.5)$ \\
Positive & $5(23.8)$ & $60(49.2)$ & $65(45.5)$ \\
\hline Total & $21(100)$ & $122(100)$ & $143(100)$ \\
\hline
\end{tabular}

CISAM: Centro Integrado de Saúde Amaury de Medeiros.

immunoglobulin secretions, local levels of CD4, Langerhans cells and concomitant infections (Mota 2002, Nicol et al. 2005, Santegoets et al. 2008). Pregnancy can hasten and intensify infection by high-risk HPV (in particular, by HPV 16) and presents highly sensitive conditions for HPV activation, persistence and transformation (Armbruster-Moraes et al. 2000). In similar studies using the same molecular test (PCR), a high prevalence of HPV was also found among HIV-positive pregnant women in different settings (Mota 2002, Bollen et al. 2006, Minkoff et al. 2006).

In a multicentre study involving seven countries, Muñoz et al. (2002) found that HPV 16 was the most common type in all of them, with percentages ranging from $43.9 \%$ (in the Philippines) to $72.4 \%$ (in Morocco). HPV 16 and 18 (Muñoz et al. 2002, Rabelo-Santos et al. 2003, Silva 2004, Fernandes et al. 2004, Ho et al. 2005, Lin et al. 2006, Wright et al. 2006) have been shown to be the types most frequently found in cervical infections, such that HPV 16 was associated with more than half of all cervical carcinoma cases (Zerbini et al. 2001) and HPV 18 with $12 \%$ (Welkovic 2007). Women who are positive for high-risk HPV DNA have a higher likelihood of developing CIN II or CIN III during follow up than do women who are negative for HPV DNA. This likelihood increases when HPV 16 or 18 is present (Wright et al. 2006).

According to Sun et al. (1997), HPV 16 and 18 are the types with the highest frequency among HIV-infected women. In the present sample, HPV 16 and 18 corresponded to the first and third most frequent types. In addition, nine patients were identified with two types of HPV, of which at least one type was high risk. This could be associated with the persistence of infection (Trotier \& Franco 2006). Mota (2002) identified a high rate of persistence of high-oncogenic-risk HPV infection (69.4\%) among HIV-positive women who were pregnant and the most frequent types were HPV 16 and 58.

HPV 58, 66, 31 and 70 were other frequently found types in the present study. Chan et al. (1999) suggested that HPV 58 also had a significant role in the aetiology of cervical carcinoma. The viral types $16,31,33,38,52$, 58 and 67 are all grouped in the same branch of the phylogenetic tree, thus indicating their similarity regarding oncogenic potential (IARC 2007). In the present study, the high prevalence of HPV 58 is in agreement with other studies that revealed the importance of this type in some regions of Brazil (North, Northeast and Centre-West) and in the Orient (Mota 2002, Câmara et al. 2003, Yokoyama et al. 2003, Clifford et al. 2005, Nicol et al. 2005, Lin et al. 2006, Wright et al. 2006, Pereira et al. 2007). The results obtained here corroborate the idea that there are regional variations of certain HPV types in Brazil (Câmara et al. 2003, Queiroz et al. 2004, Pereira et al. 2007). Attention is drawn to the high frequency of HPV 66, which was included among the high-risk types of HPV in the new IARC classification (2007). In our study, its presence was identified in 13 cases: in 10 cases alone and in association with another high-risk type in three cases.

The agreement between the molecular methods used in the present study was significant, albeit weak (Kappa $=0.119 ; \mathrm{p}=0.031)$. The PCR method was shown to be extremely sensitive, coinciding with data in the literature (Villa \& Denny 2006), whereas HC II presented a lower sensitivity, in fact, less than what other authors have reported (Dillner 2001, Castle et al. 2002, Koliopoulos et al. 2007, De Francesco et al. 2008). In a metaanalysis on tests for identifying HPV, Arbyn et al. (2006) found that the HC II method presented high sensitivity. Some of the findings responsible for the low sensitivity of HC II seen in the present study may be due to the fact that 41 of the 62 HIV-positive patients had HPV types determined using PCR that did not appear in the HC II probes. Among the 21 cases that were positive by PCR and negative by HC II and whose HPV-DNA types were contained in probes A and/or B, the number of copies was lower than the cut-off suggested by the manufacturer. For probe A, the mean was 0.27 , with a standard deviation of 0.14 (minimum 0.10 and maximum 0.89 ), while for probe $\mathrm{B}$, the mean was 0.35 with a standard deviation of 0.19 (minimum 0.14 and maximum 0.96 ).

PCR is the most sensitive technique for identifying HPV DNA (Villa \& Denny 2006, IARC 2007). Despite its unquestionable value, this technique may present false negative results. In the present study, PCR did not diagnose five patients (3.5\%) who had a positive HC II. False negative results are frequently related to the presence of inhibitors of PCR in the samples or impairment of primer-template annealing due to local DNA modifications or inappropriate annealing temperature during the cycling. The significant percentage of inflammatory processes, along with the bleeding inherent to the gestational period could have been a source of amplification inhibitors. However, it would be unlikely, since we were able to amplify the $g p d H$ gene from these five patients. The annealing temperature of the HPV-specific PCR is low to allow primer-template annealing using degenerate primers. Nevertheless, further modification of the DNA sequence could prevent primer-template annealing and amplification. The possibility of having not added the template in the reaction was not considered as the reaction was repeated more than twice.

The prevalence of IEL observed from oncotic cytological analysis in the HIV-positive groups was similar to what has been found in other studies (Levi et al. 2002, Mota 2002, Silva 2004, Silva et al. 2005, Parham et al. 2006). Parham et al. (2006) identified the presence of IEL in $114(76 \%)$ of 150 HIV-positive women who were 
examined using cytological analysis. Among these, 49 cases were high risk $(32.6 \%)$. They concluded that the presence of a high-risk HPV type was associated with the presence of severe cytological abnormality.

Despite recognising that the cervicovaginal inflammatory processes that are frequent among HIVpositive women create difficulties in the oncological interpretation of colpocytological findings, Wright et al. (1994) determined a sensitivity of $81 \%$ and a specificity of $87 \%$. To improve the accuracy of investigations, it has been recommended that colposcopic examinations should be performed in conjunction with colpocytological analysis for IEL screening (Nappi et al. 2005). A significant proportion of women with normal cytological findings have been diagnosed positive for high-risk HPV DNA by means of molecular tests. It can be inferred that such cases were either recent infections, which had not had time for cytological lesion development or slow infections that were only identified by molecular means (Fernandes et al. 2004). Another possible explanation would be the use of antiretrovirals. Low viral loads associated with TCD4 counts greater than 200 cells $/ \mathrm{mm}^{3}$ indicate immunity that has not been greatly altered in the study groups.

Women who used antiretroviral therapy have been found to present higher rates of IEL regression (Minkoff et al. 2001, Ahdieh-Grant et al. 2004). This seems plausible, since antiretroviral therapy reverses immunodeficiency, thereby increasing the number of TCD4 cells (Heard et al. 1998) and reducing the viral load (Wagner et al. 2001).

The availability of a vaccine against HPV with a selective protection spectrum for some viral types makes it important to know the regional distribution of the different types of HPV (Mammas et al. 2008). In addition to HPV 16 and 18 , which have the highest incidence worldwide, types 58 and 66 were identified, sometimes in multiple infections. These results reveal that the use of existing vaccines may not sufficiently reflect the realities of HPV in all regions (i.e., regional variations in virus type have greater importance than what was supposed) and that the planning for future immunisation programmes must respect such regional characteristics.

\section{REFERENCES}

Ahdieh-Grant L, Li R, Levine AM, Massad LS, Strickler HD, Minkoff H, Moxley M, Palefsky J, Sacks H, Burk RD, Gange SJ 2004. Highly active antiretroviral therapy and cervical squamous intraepithelial lesions in human immunodeficiency virus-positive women. J Natl Cancer Inst 96: 1070-1076.

Arbyn M, Sasieni P, Meijer Cjlm, Claved C, Koliopoulos G, Dillner J 2006. Chapter 9: Clinical applications of HPV testing: a summary of meta-analyses. Vaccine 24 (Suppl. 3): S78-89.

Armbruster-Moraes E, Toshimoto LM, Leão E, Zugaib M 2000. Prevalence of "high risk" human papillomavirus in the lower genital tract of Brazilian gravidas. Int J Gynaecol Obstet 69: 223-227.

Berek JS 2003. Simplification of the New Bethesda 2001. Classification system. Am J Obstet Gynecol 188: 2-5.

Berrébi A, Badiou W, Duclusaud A 2008. Frequency, persistence and recurrence of HPV lesions of the uterine cervix in HIV-positive women. Gynecol Obstet Fertil 36: 521-524.
Bollen LJM, Chuachoowong R, Kilmarx PH, Mappstats PAM, Culnane M, Skunodom N, Chaowanachan T, Jetswang B, Neeyapun $\mathrm{K}$, Asavapiriyanont S, Roongpisuthipong A, Wright TC, Tappero JW 2006. Human papillomavirus (HPV) detection among human immunodeficiency virus-infected pregnant Thai women: implication for future HPV immunization. Sex Transm Dis 33: 259-264.

Brandão VCRAB 2008. Fatores de risco para lesões intra-epiteliais cervicais, freqüencia e tipos de papilomavírus (HPV) em gestantes infectadas pelo vírus da imunodeficiência humana (HIV), $\mathrm{PhD}$ Thesis, Universidade Federal de Pernambuco, Recife, 148 pp.

Câmara GNL, Cerqueira DM, Oliveira APG, Silva EO, Carvalho LGS, Martins CRF 2003. Prevalence of human papillomavirus types in women with pre-neoplastic and neoplastic cervical lesions in the Federal District of Brazil. Mem Inst Oswaldo Cruz 98: 879-883.

Campos RR, Melo VH, Castilho DM, Nogueira CPF 2005. Prevalência do papilomavírus humano e seus genótipos em mulheres portadoras e não-portadoras do vírus da imunodeficiência humana. RBGO 27: 248-256.

Castellsague X, Muñoz N 2003. Chapter 3: Cofactors in human papillomavirus carcinogenesis-role of parity, oral contraceptives and tobacco smoking. J Natl Cancer Inst Monogr 31: 20-28.

Castle PE, Schiffman M, Burk RD, Wacholder S, Hildesheim A, Herrero R, Bratti MC, Sherman ME, Lorincz A 2002. Restricted crossreactivity of hybrid capture 2 with nononcogenic human papillomavirus types. Cancer Epidemiol Biomarkers Prev 11: 1394-1399.

Chan PK, Li WH, Chan MYM, Ma WL, Cheung LK, Cheng AF 1999. High prevalence of human papillomavirus type 58 in Chinese women with cervical cancer and precancerous lesions. $J$ Med Virol 59: 232-238.

Clifford GM, Gallus S, Herrero R, Muñoz N, Snijders PJF, Vaccarela S, Anh PTH, Ferreccio C, Hieu NT, Matos E, Molano M, Rajkumar R, Ronco G, Sanjosé S de, Shin HR, Sukvirach S, Thomas JO, Tunsakul S, Meijer CJLM, Franceschi S 2005. Worldwide distribution of human papillomavirus types in cytologically normal women in the International Agency for Research on Cancer HPV prevalence surveys: a pooled analysis. Lancet 366: 991-998.

Coelho RA, Figueredo MK, Nogueira AL, Sakano CRSB, Ribalta JCL, Baracat EC 2004. Relação entre diagnóstico citológico de neoplasia intra-epitelial cervical e índices de células $\mathrm{CD}^{+}$e de carga viral em pacientes HIV- soropositivas. RBGO 26: 97-102.

Correia HS, Cornetta MCM, Gonçalves AKS 2006. Infecção genital pelo papilomavírus humano (HPV) em mulheres grávidas. Rev Brasil de Genit 1: 14-19.

Costa KCBC, Pereyra EAG, Zugaib M 2000. Infecção pelo HPV durante o ciclo gravídico-puerperal. RBGO 11: 62-64.

De Francesco MA, Gargiulo F, Schreiber C, Ciravolo G, Salinaro F, Manca N 2008. Comparison of the AMPLICOR human papillomavirus test and the hybrid capture 2 assay for detection of highrisk human papillomavirus in women with abnormal PAP smear. J Virol Methods 147: 10-17.

Denny L, Boa R, Williamson AL, Allan B, Hardie D, Stan R, Myer L 2008. Human papillomavirus infection and cervical disease in human immunodeficiency virus-1-infected women. Obstet Gynecol 111: 1380-1387.

Di Felice V, David S, Cappello F, Farina F, Zummo G 2005. Is chlamydial heat shock protein 60 a risk factor for oncogenesis? Cell Mol Life Sci 62: 4-9.

Dillner J 2001. Primary screening for human papillomavirus infection. Best Pract Res Clin Obstet Gynaecol 15: 743-757.

Duerr A, Kieke B, Warrend, Shah K, Burk R, Peipert JF 2001. Human papillomavirus-associated cervical cytologic abnormalities 
among women with or at risk of infection with human immunodeficiency virus. Am J Obstet Gynecol 184: 584-590.

Ellerbrock TV, Chiasson MA, Bush TJ, Sun XW, Sawo D, Brudney K, Wright TC 2000. Incidence of cervical squamous intraepithelial lesions in HIV-infected women. JAMA 283: 1031-1037.

Ferenczy A, Coutlée F, Franco E, Hankins C 2003. Human papillomavirus and HIV coinfection and the risk of neoplasias of the lower genital tract: a review of recent developments. CMAJ 169: 431-434.

Fernandes AP, Gonçalves MAG, Simões RT, Quintana SM, Duarte G, Donadi EA 2004. Influência da infecção pelo HIV-1 sobre a presença do HPV em lesões do colo uterino. DST J Bras Doenças Sex Trans 161: 21-25.

Harris TB, Kulasingam SL, Kiviat NB, Mao C, Agoff SN, Feng Q, Koutsky LA 2004. Cigarette smoking, oncogenic human papillomavirus, KI-67 antigen and cervical intraepithelial neoplasia. Am J Epidemiol 159: 834-842.

Hawes SE, Critchlow CW, Sow PS, Tourép N, Doye I, Diop A, Kuypers JM, Kasse AA, Kiviat NB 2006. Incident high-grade sqamous intraepithelial lesions in Senegalese women with and without human immunodeficiency virus type 1( HIV-1) and HIV-2. J Natl Cancer Inst 98: 105-109.

Heard I, Schmitz V, Costagliola D, Orth G, Kazatchkine D 1998. Early regression of lesions in HIV-seropositive women receiving highly active antiretroviral therapy. AIDS 12: 1459-1464.

Hessol NA, Seaberg EC, Preston-Martin S, Massad LS, Sacks HS, Silver S, Melnick S, Abulafia O, Levine AM, WIHS Collaborative Study Group 2004. Cancer risk among participants in the women's interagency HIV study. J Acquir Immune Defic Syndr 36: 978-985.

Ho CM, Yang SS, Chien TS, Huang SH, Jeng CJ, Chang SF 2005. Detection and quantitation of human papillomavirus type 16,18 and 52 DNA in the peripheral blood of cervical cancer patients. Gynecol Oncol 99: 615-621.

IARC - International Agency for Research on Cancer 2007. Monographs on the evaluation of carcinogenic risks to humans, vol. 90, IARC, Lyon, $671 \mathrm{pp}$.

Jamieson DJ, Duerr A, Burk R, Klein RS, Paramsothy P, Schuman P POR FAVOR, COMPLETE COM O NOME DOS AUTORES 2002. Characterization of genital human papillomavirus infection in women who have or who are at risk of having HIV infection. Am J Obstet Gynecol 186: 21-27.

Koliopoulos G, Arbyn M, Martin-Hirsch P, Kyrgiou M, Prendiville W, Paraskevaidis E 2007. Diagnostic accuracy of human papillomavirus testing in primary cervical screening: a systematic review and meta-analysis of non-randomized studies. Gynecol Oncol 104: 232-246.

Levi JE, Fernandes S, Tateno AF, Motta E, Lima LP, Eluf-Neto J, Pannuti CS 2004. Presence of multiple human papilloma virus type in cervical samples from HIV-infected women. Gynecol Oncol 92: 225-231.

Levi JE, Fink MS, Canto CLM, Carretiero N, Matsubara R, Linhares I, Dolores GB, Castelo A, Segurado A, Uip D, Eluf Neto J 2002. Human papillomavirus prevalence, viral load and cervical intraepithelial neoplasia in HIV-infected women. Braz J Infect Dis 6: 129-135.

Lillo FB, Lodini S, Ferrari D, Stayton C, Taccagni G, Galli L, Lazzarin A, Uberti-Foppa C 2005. Determination of human papillomavirus (HPV) load and type in high-grade cervical lesions surgically resected from HIV-infected women during follow-up of HPV infection. Clin Infect Dis 40: 451-457.

Lin H, Ma Y, Moh J, Ou Y, Shen S, Chang Chien C 2006. High prevalence of genital human papillomavirus type 52 and 58 infection in women attending gynecologic practitioners in South Taiwan. Gynecol Oncol 101: 40-45.

Madeleine MM, Anttila T, Schwartz SM, Saikku P, Leinonen M, Carter JJ 2007. Risk of cervical cancer associated with Chlamydia trachomatis antibodies by histology, HPV type and HPV cofactors. Int J Cancer 120: 650-655.

Mammas IN, Vageli D, Spandidos DA 2008. Geographic variations of human papilloma virus infection and their possible impact on the effectiveness of the vaccination programme. Oncol Rep 20: $141-145$.

Manos MM, Ting Y, Wright DK, Lewis AJ, Broker TR, Wollinsky SM 1989. The use of polymerase chain reaction amplification for the detection of genital human papillomaviruses. Cancer Cells 7: 209-214.

Meisels SJ 1992. Doing harm by doing good: iatrogenic effects of early childhood enrollment and promotion policies. Early Child Res $Q$ 7: 155-175.

Minkoff H, Ahdieh L, Massad LS, Anastos K, Watts DH,Melnick S, Muderspach L, Burk R, Palefsky J 2001. The effect of highly active antiretroviral therapy on cervical cytologic changes associated with oncogenic HPV among HIV-infected women. AIDS 15: 2157-2164.

Minkoff H, Lin SX, Watts DH, Leighty R, Hershow R, Palefsky J, Tuomala R, Neu N, Zorrilla CD, Paul M, Strickler H 2006. Relationship of pregnancy to human papillomavirus among human immunodeficiency vírus-infected women. Obst Gynecol 108: 953-960.

Moreno V, Bosch FX, Munoz N, Meijer CJ, Shah KV, Walboomers JM, Herrero R, Franceschi S 2002. Effect of oral contraceptives on risk of cervical cancer in women with human papillomavirus infection: the IARC multicentric case-control study. Lancet 359: 1085-1092.

Mota GR 2002. Avaliação da infecção e caracterização de tipos de papilomavirus humano (HPV) em gestantes infectadas pelo vírus da imunodeficiência humana (HIV-1), PhD Thesis, Escola Paulista de Medicina, São Paulo, 89 pp.

MS - Ministério da Saúde 2005. Coordenação Nacional de DST/AIDS. Manual de controle das doenças sexualmente transmissiveis, $4^{\mathrm{a}}$ ed., MS, Brasília, 142 pp.

Muñoz N, Bosch FX, Sanjosé S, Herrero R, Castellsague X, Shah KV, Snijders PJ, Meijer CJ 2003. Epidemiologic classification of human papilloma virus types associated with cervical cancer. N Engl J Med 345: 518-527.

Muñoz N, Castellsague X, de González AB, Grissmann L 2006. Chapter 1: HPV in the etiology of human cancer. Vaccine 24: S1-10.

Munoz N, Franceschi S, Bosetti C, Moreno V, Herrero R, Smith JS, Shan KV, Meijer CJ, Bosch FX 2002. Role of parity and human papillomavirus in cervical cancer: the IARC multicentric casecontrol study. Lancet 359: 1093-1101.

Nappi L, Carriero C, Bettocchi S, Herrero J, Vimercati A, Pano G 2005. Cervical squamous intraepithelial lesions of low-grade in HIV-infected women: recurrence, persistence and progression, in treated and untreated women. Eur J Obstet Gynecol Reprod Biol 121: $226-232$

Nicol AF, Feranades ATG, Bonecini-Almeida MG 2005. Immune response in cervical dysplasia induced by human papillomavirus: the influence of human immunodeficiency virus-1 co-infection - A Review. Mem Inst Oswaldo Cruz 100: 1-12.

Palefsky J 2006. Human papillomavirus-related tumors in HIV. Curr Opin Oncol 18: 463-468.

Parham GP, Sarasrabuddhe VV, Mwanahamuntu MH, Shepherd BE, Hicks ML, Stringer EM, Vermund SH 2006. Prevalence and predictors of squamous intraepithelial lesions of the cervix in HIV-infected women in Lusaka, Zambia. Gynecol Oncol 103: 1017-1022. 
Pereira CRN, Rosa MLG, Vasconcelos GALBM, Faria PCP, Cavalcanti SMB, Oliveira LHS 2007. Human papillomavirus prevalence and predictors for cervical cancer among high-risk women from Rio de Janeiro. Int J Gynecol Cancer 17: 651-660.

Puig-Tintoré LM, Menendez AA, Bordoy XC, Bosch FX, Bladé AT, Castellsague X 2002. La infección por papilomavirus, Documentos de consenso, SEGO, Barcelona, $56 \mathrm{pp}$.

Queiroz C, Travassos AG, Studart E, Araújo Filho JB, Sarno CK, Pinheiro CC 2004. Prevalence of human papilloma virus in HIVpositive and HIV-negative patients in the state of Bahia. A pilot study. Braz J Infect Dis 8: 356-362.

Rabelo-Santos SH, Zeferino L, Villa LL, Sobrinho JP, Amaral RG, Magalhães AV 2003. Human papillomavirus prevalence among women with cervical intraepithelial neoplasia III and invasive cervical cancer from Goiânia, Brazil. Mem Inst Oswaldo Cruz 98: 181-184.

Rando RF, Lindheim S, Hasty L, Sedlacek TV, Woodland M, Eder C 1989. Increased frequency of detection of human papillomavirus deoxyribonucleic acid in exfoliated cervical cells during pregnancy. Am J Obstet Gynecol 161: 50-55.

Santegoets LA, van Seters M, Heijmans-Antonissen C, Kleinjan A, van Beurden M, Ewing PC, Kühne LC, Beckmann I, Burger CW, Helmerhorst TJ, Blok LJ 2008. Reduced local immunity in HPVrelated VIN: expression of chemokines and involvement of immunocompetent cells. Int J Cancer 123: 616-622.

Schneider A, Hotz M, Gissmann L 1987. Increased prevalence of human papillomavirus in the lower genital tract of pregnant women. Int J Cancer 40: 198-201.

Silva RJ, Athayde MJPM, Pedrosa ML, Fialho SCAV, Russomano FB, Grinsztejn B, Silva LGP 2005. Lesões intra-epiteliais vulvares em pacientes infectadas pelo HIV. RBGO 27: 407-414.

Silva TT 2004. Fatores de risco para neoplasia intra-epitelial cervical em pacientes submetidas à avaliação morfológica e pesquisa de $D N A / H P V$, PHD Thesis, Universidade Federal de Pernambuco, Recife, 130 pp.

Sun XW, Kuhn L, Ellenbrock TV, Chiasson MA, Bush TJ, Wright TC 1997. Human papillomavirus infection in women infected with the human immunodeficiency virus. $N$ Engl J Med 337: 1343-1349.
Trotier H, Franco EL 2006. The epidemiology of genital human papillomavirus infection. Vaccine 24 (Suppl. 1): S1-15.

Villa LL, Denny L 2006. Methods for detection of HPV infection and its clinical utility. Int J Gynaecol Obstet 94: S71-80.

Wagner TM, Pezzotti P, Valdarchi C, Rezza G 2001. Different pattern of AIDS-defining diseases in persons responding to highly active antiretroviral therapy. J Acquir Immune Defic Syndr 26: 394-395.

Walker P, Dexeus S, De Palo G, Barrasso R, Campion M, Girardi F, Jacob C, Roy M 2003. International terminology of colposcopy: an update report from the International Federation for Cervical Pathology and Colposcopy. Obstet Gynecol 101: 175-177.

Wright TC, Bosch FX, Franco EL, Cuzick J, Schiller JT, Garnett GP, Meheus A 2006. Chapter 30: HPV vaccines and screening in the prevention of cervical cancer; conclusions from 2006 workshop of international experts. Vaccine 24: S251-261.

Wright TC, Ellerbrock TV, Chiasson MA, Van Devanter N, Sun XW 1994. Cervical intraepithelial neoplasia in women infected with human immunodeficiency virus: prevalence, risk factors, and validity of Papanicolau smears. Obstet Gynecol 84: 591-597.

Welkovic S 2007. Células de Langerhans em mulheres HIV-soropositivas com neoplasia intraepitelial cervical, PHD Thesis, Universidade Federal de Pernambuco, Recife, 132 pp.

Yokoyama M, Iwasaka T, Nagata C, Nozawa S, Sekiya S, Hirai Y, Kanazawa K, Sato S, Hoshiai H, Sugase M, Kawana T, Yoshikawa H 2003. Prognostic factors associated with the clinical outcome of cervical intraepithelial neoplasia: a cohort study in Japan. Cancer Lett 192: 171-179.

Zerbini M, Venturoli S, Cricca M, Gallinella G, De Simone P, Costa S, Santini D, Musiani M 2001. Distribution and viral load of type specific HPVs in different cervical lesions as detected by PCRELISA. J Clin Pathol 54: 377-380.

Zimmermmann JB, Melo VH, Castro PF, Alves MJM, Zimmermmann SG, Del Castillo DM 2006. Associação entre a contagem de linfócitos T CD4 e a gravidade da neoplasia intra-epitelial cervical diagnosticada pela histopatologia em mulheres infectadas pelo HIV. RBGO 28: 345-351. 